\title{
Effect of High Glucose Concentration on the Synthesis of Monocyte Chemoattractant Protein-1 in Human Peritoneal Mesothelial Cells: Involvement of Protein Kinase C
}

\author{
Bettina Haslinger $^{a}$ Sonja Mandl-Weber ${ }^{a}$ Alois Sellmayer ${ }^{b}$ \\ Stephan R. Lederer ${ }^{\mathrm{a}}$ Thomas Sitter $^{\mathrm{a}}$

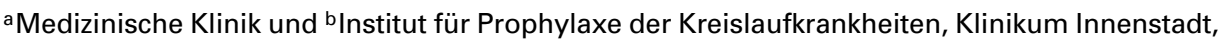 \\ Ludwig-Maximilians-Universität, München, Deutschland
}

\section{Key Words}

Mesothelial cells - Glucose $\cdot$ Monocyte chemoattractant protein-1 1 Peritoneal dialysis

\begin{abstract}
Human peritoneal mesothelial cells (HMC) contribute to the activation and control of inflammatory processes in the peritoneum by their potential to produce various inflammatory mediators. The present study was designed to assess the effect of glucose, the osmotic active compound in most commercially available peritoneal dialysis fluids, on the synthesis of the $\mathrm{C}-\mathrm{C}$ chemokine monocyte chemoattractant protein-1 (MCP-1) in cultured HMC. The MCP-1 concentration in the cell supernatants was determined by enzyme-linked immunosorbent assay and the MCP-1 mRNA expression was examined using Northern blot analysis. Incubation of HMC with glucose (30-120 $\mathrm{mM}$ ) resulted in a time- and concentration-dependent increase in MCP-1 protein secretion and mRNA expression. After $24 \mathrm{~h}$ the MCP-1 synthesis was increased from $2.8 \pm 0.46$ to $4.2 \pm 0.32 \mathrm{ng} / 10^{5}$ cells $(\mathrm{n}=$ $5, \mathrm{p}<0.05)$ in HMC treated with $60 \mathrm{~m} M$ glucose. In contrast, osmotic control media containing either the meta-
\end{abstract}

\begin{tabular}{ll}
\hline KARGER & ( ) 2001 S. Karger AG, Basel \\
$0028-2766 / 01 / 0874-0346 \$ 17.50 / 0$ \\
$\begin{array}{l}\text { Fax +4161306 1234 } \\
\begin{array}{l}\text { E-Mail karger@karger.ch } \\
\text { www.karger.com }\end{array}\end{array}$ & $\begin{array}{l}\text { Accessible online at: } \\
\text { www.karger.com/journals/nef }\end{array}$
\end{tabular}

bolically inert monosaccharide mannitol or $\mathrm{NaCl}$ did not influence MCP-1 production. The stimulating effect of high glucose on MCP-1 expression in HMC was mimicked by activation of protein kinase $C$ (PKC) with the phorbol ester PMA (20 nM). Coincubation of the cells with glucose and the specific PKC inhibitor Ro 31-8220 completely blunted glucose-mediated MCP-1 expression. In summary, our results indicate that glucose induces MCP-1 synthesis by a PKC-dependent pathway. Since osmotic control media did not increase MCP-1 release, it is suggested that the effect of glucose is mainly related to metabolism and not to hyperosmolarity. These data may in part explain elevated steady-state levels of MCP-1 found in the dialysis effluent of continuous ambulatory peritoneal dialysis patients.

Copyright $@ 2001$ S. Karger AG, Basel

\section{Introduction}

Mesothelial cells constitute the main cell population of the peritoneal membrane. Besides being an active permeability barrier during continuous ambulatory peritoneal dialysis (CAPD), the mesothelium is in close proximity to

Dr. Thomas Sitter

Medizinische Klinik, Klinikum Innenstadt der Universität München

Ziemssenstrasse 1, D-80336 München (Germany)

Tel. +49 8951602129 , Fax +49 8951604924

E-Mail tsitter@medinn.med.uni-muenchen.de 
the underlying peritoneal capillaries and has significant potential to contribute to the activation and control of inflammatory processes in the peritoneal cavity [1]. In response to bacteria or proinflammatory cytokines, human peritoneal mesothelial cells (HMC) produce various inflammatory mediators including adhesion molecules (VCAM, ICAM) [2, 3], cytokines (interleukin (IL)-1 and IL-6) $[4,5]$, and the chemokines IL-8, RANTES and monocyte chemoattractant protein-1 (MCP-1) [6-8]. Recently it has been found that also chemokine receptors are expressed by mesothelial cells [9]. MCP-1 belongs to the $\mathrm{C}-\mathrm{C}$ chemokine family and has chemotactic activity for mononuclear cells [10]. Although the precise cellular signaling mechanisms that control neutrophilic and monocytic cell infiltrate into the peritoneal cavity are not fully understood, MCP-1 has been shown to be a potent monocyte chemoattractant and activator, which leads to the influx of monocytes in inflammatory tissue $[11,12]$. In addition, in vitro studies demonstrate that $\mathrm{C}-\mathrm{C}$ and $\mathrm{C}-\mathrm{X}-\mathrm{C}$ chemokines are involved in the migration of leukocytes across mesothelium [13].

In recent studies, high levels of MCP-1 were detected in the effluent of CAPD patients suffering from peritonitis $[11,14,15]$. Since in the initial phase of peritonitis only a small number of resident macrophages are present in the peritoneum, it has been hypothesized that besides macrophages also HMC account for the MCP-1 production in the peritoneal cavity [15]. This assumption is supported by the finding that not only during episodes of peritonitis but also in clinically stable CAPD patients high steady-state levels of MCP-1 were found in the dialysis effluent [11]. The underlying mechanism of this persistent MCP-1 production during CAPD is still unclear. It has been speculated that the dialysis solutions, to which the HMC are exposed after each dialysate exchange, can cause a sterile inflammatory state [16], which may be reflected by enhanced MCP-1 synthesis in HMC.

Conventional dialysis solutions are hyperosmolar, usually by high glucose concentrations, and have a low $\mathrm{pH}$. Previous studies indicate that the metabolic effect of high glucose as well as its hyperosmolar concentration in the dialysate compromise the function and metabolism of HMC [17]. Accordingly, we recently demonstrated that high glucose concentrations enhance the production of prostaglandins and tissue type plasminogen activator in HMC $[18,19]$. In the present study we assessed the effect of glucose on the expression of MCP-1 in HMC.

\section{Materials and Methods}

\section{Materials}

M199 medium and newborn calf serum were obtained from Gibco-BRL (Eggenstein, Germany); tissue culture plates were from Costar (Cambridge, Mass., USA). Human serum was prepared from freshly collected blood of healthy donors and stored at $-20^{\circ} \mathrm{C}$. Fibronectin from human serum and trypsin were purchased from Boehringer Mannheim (Mannheim, Germany). Collagenase type II was from Worthington (Freehold, N.Y., USA). D-Glucose, mannitol

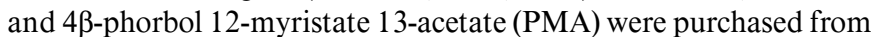
Sigma (Munich, Germany). The PKC inhibitor Ro 31-8220 was a generous gift from Dr. G. Lawton (Hoffmann-La Roche, Welwyn Garden City, UK) [20]. Monoclonal antibodies against cytokeratins 8 and 18 and against vimentin were a gift from Dr. G. van Muijen (University of Nijmegen, The Netherlands).

\section{Cell Culture Experiments}

HMC were isolated from the omental tissue of consenting patients undergoing elective surgery as described previously [21]. Cells were grown in fibronectin-coated dishes in M199 medium supplemented with $25 \mathrm{~m} M$ Hepes (pH 7.3), $2 \mathrm{~m} M$ glutamine, $10 \%$ (v/v) human serum (HS), 10\% (v/v) newborn calf serum (heat-inactivated), penicillin $(100 \mathrm{IU} / \mathrm{ml})$ and streptomycin $(100 \mu \mathrm{g} / \mathrm{ml})$ at $37^{\circ} \mathrm{C}$ under $5 \% \mathrm{CO}_{2} / 95 \%$ air atmosphere. The medium was replaced every 2-3 days. Subcultures were obtained by trypsin/EDTA treatment at a split ratio of 1:3. Cells from omental tissue were pure mesothelial cells as assessed by their uniform cobblestone appearance at confluence, by the absence of von Willebrand factor and the uniform positive staining for cytokeratins 8 and 18 and for vimentin [21]. For the experiments, confluent cultures were used at the second or third passage, and cells were always refed $24 \mathrm{~h}$ before the experiment with M199, supplemented with $2 \%(\mathrm{v} / \mathrm{v})$ HS, and antibiotics. All the experiments were done with M199+2\% HS supplemented with the stimuli. Incubation of cells with doses of tested compounds for up to $24 \mathrm{~h}$ did not have any significant effect on cell viability as tested by vital cell staining with acridine orange and ethidium bromide and by LDH release (cell viability exceeded $95 \%$ ). Conditioned media were obtained by incubating cells in $2-\mathrm{cm}^{2}$ dishes at $37^{\circ} \mathrm{C}$ for $1-24 \mathrm{~h}$ with $0.5 \mathrm{ml}$ incubation medium containing the appropriate concentration of the test compound or stock solvent. Conditioned media were centrifuged $5 \mathrm{~min}(2,000 \mathrm{~g})$ to remove cells and cellular debris, and samples were frozen at $-20^{\circ} \mathrm{C}$ until use.

\section{Assays}

Extracellular immunoreactive MCP-1 was measured using the Immunoassay Kit from BioSource International (USA) following the manufacturer's instructions. Diluted aliquots of the cell supernatants were assayed without prior purification.

\section{RNA Isolation and Northern Blotting}

Total RNA was extracted from cells as described by Chomczynski and Sacchi [22]. RNA samples were dissolved in $\mathrm{H}_{2} \mathrm{O}$. The RNA concentration in each sample was determined spectrophotometrically. Equal amounts of RNA from different dishes were analyzed for their MCP-1 and glyceraldehyde-3-phosphate dehydrogenase (GAPDH) mRNA content by Northern blot hybridization. With Northern blotting, RNA samples were subjected to gel electrophoresis in formaldehyde-agarose gels. After electrophoresis, RNA was transferred to a Nytran membrane. Hybridization was usually per- 


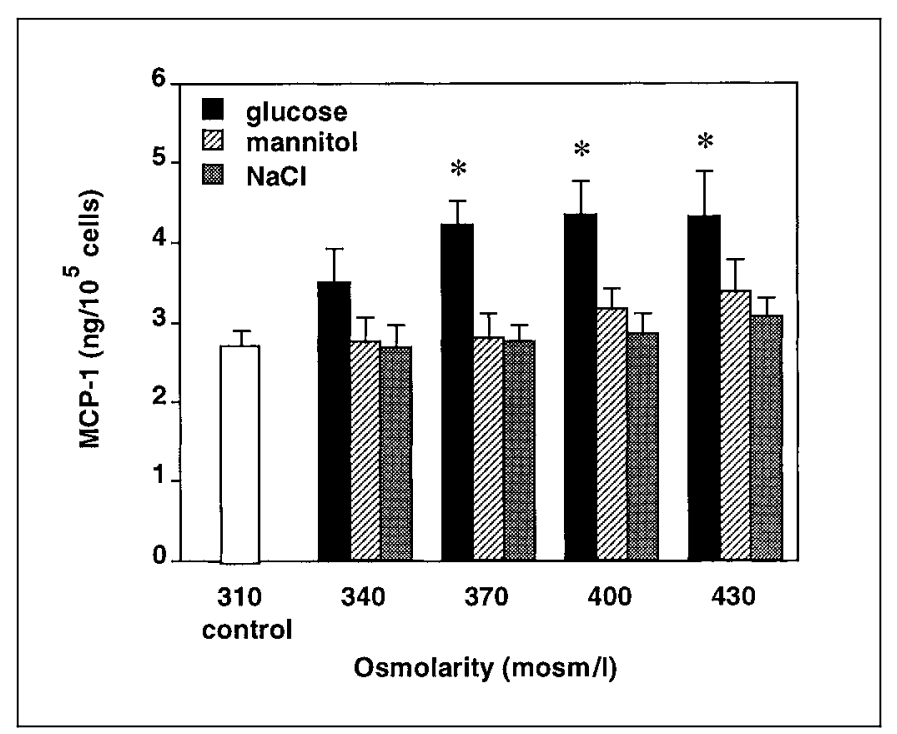

Fig. 1. Effect of increasing concentrations of glucose on MCP-1 synthesis in HMC. HMC were incubated with control medium (310 mosm/l), glucose, mannitol $(30,60,90,120 \mathrm{mM})$ or $\mathrm{NaCl}$ to achieve an osmolarity of $340-430 \mathrm{mosm} / \mathrm{l}$. MCP-1 levels were assayed in conditioned medium obtained after $24 \mathrm{~h}$ of incubation. Values are means \pm SEM of 5 independent experiments. ${ }^{*} \mathrm{p}<0.05$ compared with control.

formed at $62^{\circ} \mathrm{C}$ with $1 \mathrm{ng} / \mathrm{ml}$ of probe labeled by random prime labeling (Megaprime, Amersham, Germany) to approximately $2 \times$ $10^{8} \mathrm{cpm} / \mu \mathrm{g}$ DNA. The membranes were subsequently exposed to Amersham Hyperfilm-MP with an intensifying screen at $-80^{\circ} \mathrm{C}$.

\section{cDNA Probes}

The following cDNA fragments were used as probes in the hybridization experiments: a $0.7-\mathrm{kb}$ Bam HI fragment of the mouse JE/MCP-1 gene and a $0.8-\mathrm{kb}$ Hind III fragment of the human GAPDH gene.

\section{Statistical Analysis}

Data are given as mean \pm SEM. Statistical analysis was performed using the Wilcoxon matched-pairs signed-ranks test for nonparametric data and a $\mathrm{p}$ value $<0.05$ was considered to indicate statistically significant differences.

\section{Results}

\section{Effect of Glucose on the MCP-1 Protein Synthesis in $H M C$}

To assess the effect of glucose on MCP-1 synthesis in HMC, confluent cells were incubated with increasing concentrations (30-120 $\mathrm{mM})$ of glucose for $24 \mathrm{~h}$. The range of the glucose concentration from 30 to $120 \mathrm{mM}$ corre-

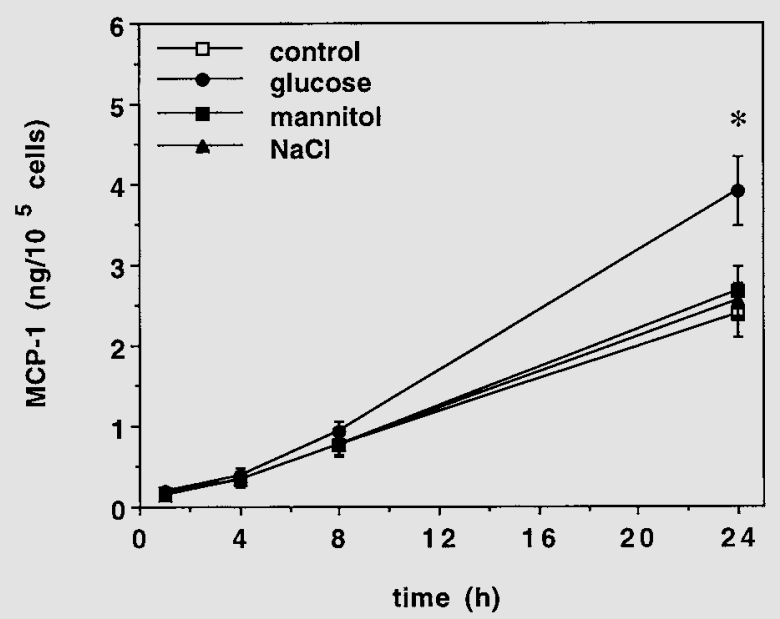

Fig. 2. Time course of MCP-1 synthesis in HMC exposed to control medium ( $\square$ ) or stimulating media containing $90 \mathrm{~m} M$ glucose (४), $90 \mathrm{~m} M$ mannitol $(\boldsymbol{\square})$ or $\mathrm{NaCl}(\boldsymbol{\Delta})$ producing an osmolarity of $400 \mathrm{mosm} / 1$. MCP-1 levels were assayed in conditioned medium obtained after different incubation times (1-24 h). Values are means \pm SEM of 4 independent experiments. ${ }^{*} \mathrm{p}<0.05$ compared with control.

sponds to intraperitoneal concentrations found in CAPD patients between 15 and $240 \mathrm{~min}$ after instillation of a $2.27 \%(=126 \mathrm{mM})$ glucose-based dialysis solution. As shown in figure 1, the addition of glucose resulted in a dose-dependent increase in MCP-1 protein concentration in the cell supernatants being statistically significant at a concentration of $60 \mathrm{mM}$ (control $2.8 \pm 0.46$ vs. glucose $4.2 \pm 0.32 \mathrm{ng} / 10^{5}$ cells, $\left.\mathrm{n}=5\right)$.

To further investigate whether stimulation of MCP-1 synthesis by glucose was related to hyperosmolarity or other, possibly metabolic effects, the cells were in parallel incubated with increasing concentrations of the metabolically inert monosaccharide mannitol or of the crystalloid agent $\mathrm{NaCl}$ (fig. 1). The medium osmolarity was increased by addition of mannitol or $\mathrm{NaCl}$ to achieve the same osmolarity caused by glucose (the concentration of 30-120 $\mathrm{m} M$ glucose or mannitol corresponds to the osmolarity of 340-430 mosm/l). As shown in figure 1, mannitol and $\mathrm{NaCl}$ did not influence MCP-1 protein levels. These results indicate that the enhanced MCP-1 production is a specific effect of the high glucose medium and is not related to changes in extracellular osmolarity.

The stimulatory effect of glucose $(90 \mathrm{mM})$ was also time-dependent. As demonstrated in figure 2, MCP-1 lev- 


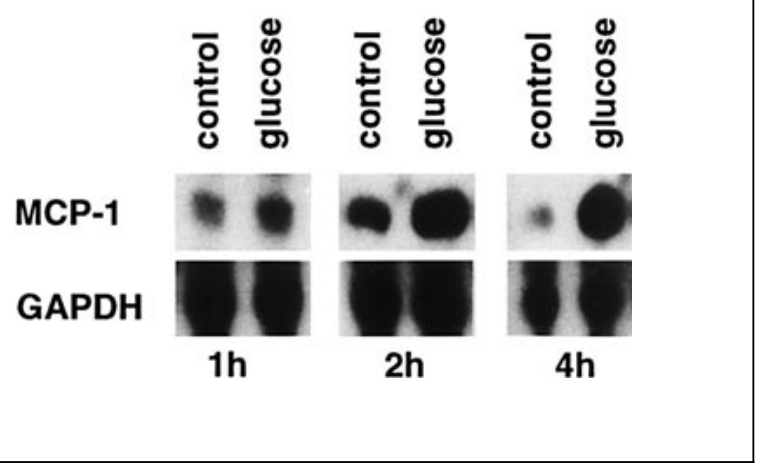

Fig. 3. $\mathrm{MCP}-1$ mRNA expression by $\mathrm{HMC}$ in response to control medium or glucose $(90 \mathrm{mM})$. HMC were incubated for 1,2 and $4 \mathrm{~h}$ in M199 supplemented as indicated and total RNA was extracted from cells and analyzed by Northern blot hybridization for MCP-1 and GAPDH.

els increased continuously reaching statistically significant differences after $24 \mathrm{~h}$. Again the effect was not reproduced by exposure to either of the osmotic control media.

\section{Effect of Glucose on the MCP-1 mRNA Expression in} $H M C$

A Northern blot analysis was performed to find out whether the elevated MCP-1 levels in the presence of glucose were related to increased MCP-1 mRNA expression. $\mathrm{HMC}$ were stimulated with glucose for various time periods, and total RNA was extracted. Figure 3 shows that glucose constantly increased MCP-1 mRNA accumulation. MCP-1 mRNA levels peaked between 2 and $4 \mathrm{~h}$. MCP-1 mRNA levels also slightly increased in unstimulated cells, which may be caused by mechanical irritation of medium exchange. Nevertheless, cells incubated with high glucose medium constantly displayed higher steadystate mRNA levels for MCP-1 when compared with the corresponding control.

\section{Role of Protein Kinase C (PKC) in Glucose-Induced}

\section{MCP-1 Synthesis}

Since activation of $\mathrm{PKC}$ by high glucose conditions has been observed in different cell types [23], we further investigated whether the effect of glucose on MCP-1 expression is mediated by a PKC-sensitive pathway in HMC. As shown in figure 4a, exposing cultured HMC to PMA, an active phorbol ester, at a concentration of $20 \mathrm{nM}$ for $24 \mathrm{~h}$ resulted in an almost 2-fold increase in MCP-1

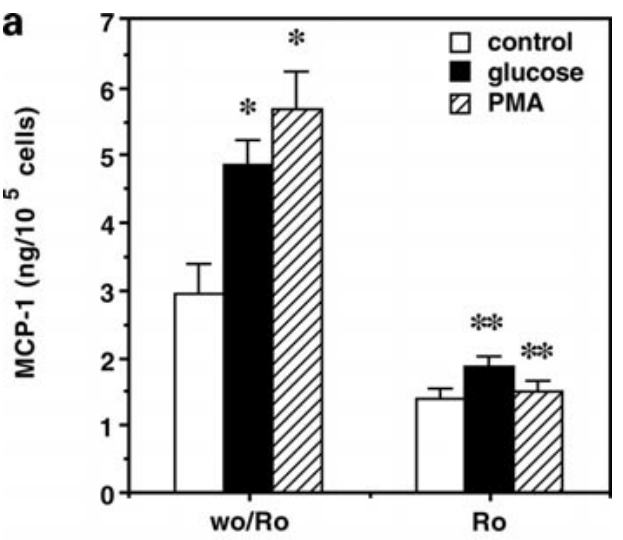

b
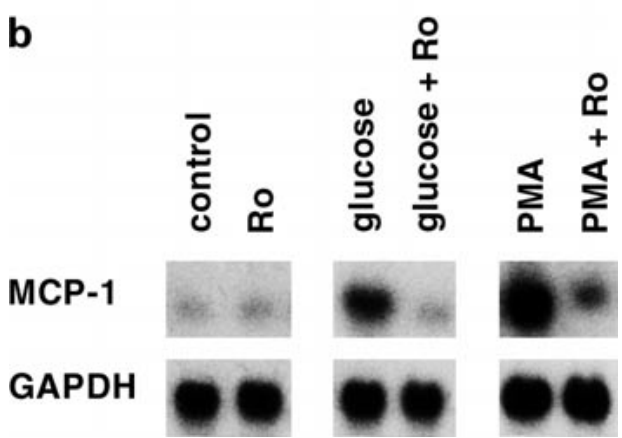

Fig. 4. a Inhibition of glucose $(90 \mathrm{~m} M)$ - or PMA (20 $\mathrm{n} M)$-induced MCP-1 synthesis by the PKC inhibitor Ro 31-8220 (Ro: Ro 318220 (3 $\mu M$ ); wo/Ro: without Ro 31-8220). MCP-1 levels were assayed in conditioned medium obtained after $24 \mathrm{~h}$ incubation of HMC in media supplemented as indicated. Values are means \pm SEM of 4 independent experiments. ${ }^{*} \mathrm{p}<0.05$ compared to control conditions (wo/Ro). ${ }^{* *} \mathrm{p}<0.05$ compared to glucose or PMA. b Inhibition of glucose $(90 \mathrm{~m} M)$ - or PMA $(20 \mathrm{n} M)$-induced MCP-1 mRNA expression by the PKC inhibitor Ro 31-8220 (Ro: Ro 31-8220 $(3 \mu M))$. HMC were incubated for $2 \mathrm{~h}$ in media supplemented as indicated and total RNA was extracted from cells and analyzed by Northern blot hybridization for MCP-1 and GAPDH.

synthesis, which is comparable to the effect of glucose. Similar effects of PMA were observed on the expression of the MCP-1 gene (fig. 4b). Coincubation with the specific PKC inhibitor Ro 31-8220 completely inhibited the stimulatory effect of PMA as well as the stimulatory effect of glucose on MCP-1 synthesis (fig. 4a). According to that, Ro 31-8220 completely abrogated the PMA and glucoseinduced increase in MCP-1 mRNA levels. These data 
indicate that activation of $\mathrm{PKC}$ is required to transduce the effect of glucose on MCP-1 gene expression and protein synthesis.

\section{Discussion}

Mesothelial cells are known to actively participate in peritoneal or pleural inflammation by the release of chemokines, including IL-8, RANTES and the chemoattractant protein MCP-1 $[1,6]$. MCP-1 is produced by HMC in response to IL-1, TNF- $\alpha$, interferon- $\gamma$ and LPS [6]. It has been demonstrated in vitro and in an animal model that MCP-1 plays a critical role in regulating the migration of mononuclear cells across the mesothelium which takes place in the inflammatory response during bacterial infection $[11,12]$. The present study demonstrates that high glucose upregulates the expression of $\mathrm{MCP}-1$ at the mRNA and protein levels in a concentration-dependent manner independent of proinflammatory mediators. Since HMC are continuously exposed to glucose during peritoneal dialysis with most available hyperosmolar dialysis solutions, these in vitro observations may also be of relevance in vivo. In confirmation, high levels of MCP-1 have been detected in the dialysis effluent of CAPD patients without infections as compared to the MCP-1 protein in the peritoneal fluid of healthy controls [11]. Taken together, it is indicated that high glucose concentrations in dialysis solutions may at least in part account for elevated MCP-1 concentrations in the peritoneal effluent and contribute to a sterile inflammatory state. This may explain that during CAPD a population of resident macrophages of monocytic origin is found in the peritoneal effluent even in the absence of inflammation, i.e. without the presence of neutrophils [16]. In contrast, the che- mokine RANTES, also a chemoattractant protein which is produced in mesothelial cells, could not be detected in stable effluents [11] and was not inducible by glucose in our experiments (data not shown). Since metabolically inert osmotic solutes - mannitol and $\mathrm{NaCl}$ - did not influence MCP-1 production, our data indicate that increased MCP-1 synthesis in response to glucose is mediated by a specific metabolic effect.

Several reports have demonstrated that high glucose exerts its effects on cultured cells by the generation of diacylglycerol which can activate PKC [23]. Thus, we have previously shown that high glucose increases $\mathrm{PGE}_{2}$ synthesis in HMC via a PKC-dependent pathway [18]. In parallel to these observations, glucose-induced MCP-1 synthesis was also sensitive to a PKC-mediated pathway, since the specific PKC inhibitor Ro 31-8220 completely inhibited the stimulatory effects of glucose and PMA. In confirmation, MCP-1 expression in response to glucose has been found to be sensitive to the PKC signal transduction pathway in human mesangial cells [24].

In conclusion, we demonstrate that MCP-1 gene expression and protein synthesis in HMC is induced by high glucose concentrations. Our results strongly suggest that the effect of glucose is specific and involves activation of PKC. Current dialysis solutions containing high glucose concentrations may induce at least a transitory increase in intraperitoneal MCP-1 levels which may contribute to the influx of relatively immature macrophages into the peritoneal cavity of stable CAPD patients.

\section{Acknowledgments}

This work was supported by grants from the Deutsche Forschungsgemeinschaft (Si-504/2-1) and the Else Kröner-FreseniusStiftung to T.S.

\section{References}

1 Topley N, Williams JD: Role of the peritoneal membrane in the control of inflammation in the peritoneal cavity. Kidney Int Suppl 1994; 48:71-78.

2 Jonjic N, Peri G, Bernasconi S, Sciacca FL, Colotta F, Pelicci P, Lanfrancone L, Mantovani A: Expression of adhesion molecules and chemotactic cytokines in cultured human mesothelial cells. J Exp Med 1992;176:11651174 .
3 Cannistra SA, Ottensmeier C, Tidy J, De Franzo B: Vascular cell adhesion molecule-1 expressed by peritoneal mesothelium partly mediates the binding of activated human T lymphocytes. Exp Hematol 1994;22:996-1002.

4 Topley N, Brown Z, Jorres A, Westwick J, Davies M, Coles GA, Williams JD: Human peritoneal mesothelial cells synthesize interleukin-8. Synergistic induction by interleukin-1-beta and tumor necrosis factor-alpha. Am J Pathol 1993; 142:1876-1886.

5 Douvdevani A, Rapoport J, Konforty A, Argov S, Ovnat A, Chaimovitz C: Human peritoneal mesothelial cells synthesize IL-1-alpha and -beta. Kidney Int 1994;46:993-1001.
6 Antony VB, Hott JW, Kunkel SL, Godbey SW, Burdick MD, Strieter RM: Pleural mesothelial cell expression of C-C (monocyte chemotactic peptide) and C-X-C (interleukin-8) chemokines. Am Respir Cell Mol Biol 1995; 12:581588.

7 Visser CE, Tekstra J, Brouwer-Steenbergen JJ, Tuk CW, Boorsma DM, Sampat-Sardjoepersad SC, Meijer S, Krediet RT, Beelen RH: Chemokines produced by mesothelial cells: huGRO-alpha, IP-10, MCP-1 and RANTES. Clin Exp Immunol 1998;1 12:270-275. 
8 Goodman RB, Wood RG, Martin TR, HansonPainton O, Kinasewitz GT: Cytokine-stimulated human mesothelial cells produce chemotactic activity for neutrophils including NAP-1/ IL-8. J Immunol 1992;148:457-465.

9 Banas B, Sitter T, Fischereder M, Banas B, Luckow B, Schlöndorff D: Human peritoneal mesothelial cells express receptors for $\mathrm{CC}$ chemokines, CXC chemokines and fractalkine. J Am Soc Nephrol 1999;10:A2562:507 A.

10 Schlondorff D, Nelson PJ, Luckow B, Banas B: Chemokines and renal disease. Kidney Int 1997;51:610-621

11 Tekstra J, Visser CE, Tuk CW, Brouwer Steenbergen JJ, Burger CW, Krediet RT, Beelen RH Identification of the major chemokines that regulate cell influxes in peritoneal dialysis patients. J Am Soc Nephrol 1996; 7:2379-2384.

12 Ajuebor MN, Flower RJ, Hannon R, Christie M, Bowers K, Verity A, Perretti M: Endogenous monocyte chemoattractant protein-1 recruits monocytes in the zymosan peritonitis model. J Leukoc Biol 1998;63:108-116.

13 Robson RL, Witowski J, Loetscher P, Williams JD, Topley N: Control of leukocyte migration across the mesothelium by IFN involves differential regulation of C-C and C-X-C chemokine production. Perit Dial Int 1998;18:118.
14 Sach M, Loetscher P, Burger JA, Knopf HP, Schollmeyer P, Dobos GJ: MCP-1 levels are elevated in peritonitis fluid from CAPD patients due to secretion by peritoneal macrophages. Adv Perit Dial 1995;11:19-23.

15 Sach M, Bauermeister K, Burger JA, Loetscher $\mathrm{P}$, Elsner J, Schollmeyer P, Dobos GJ: Inverse MCP-1/IL-8 ratio in effluents of CAPD patients with peritonitis and in isolated cultured human peritoneal macrophages. Nephrol Dial Transplant 1997;12:315-320.

16 Bos HJ, Struijk DG, Tuk CW, de Veld JC, Helmerhorst TJ, Hoefsmit EC, Arisz L, Beelen $\mathrm{RH}$ : Peritoneal dialysis induces a local sterile inflammatory state and the mesothelial cells in the effluent are related to the bacterial peritonitis incidence (letter). Nephron 1991;59:508509.

17 Breborowicz A, Oreopoulos DG: Biocompatibility of peritoneal dialysis solutions. Am J Kidney Dis 1996;27:738-743.

18 Sitter T, Haslinger B, Mandl S, Fricke H, Held E, Sellmayer A: High glucose increase prostaglandin $\mathrm{E}_{2}$ synthesis in human peritoneal mesothelial cells: Role of hyperosmolarity. J Am Soc Nephrol 1998;9:2005-2012.
19 Sitter T, Mandl-Weber S, Wörnle M, Haslinger B, Goedde M, Kooistra T: D-Glucose increases the synthesis of tissue-type plasminogen activator in human peritoneal mesothelial cells. Thromb Haemost 1999;82:1171-1177.

20 Davis PD, Hill CH, Keech E, Lawton G, Nixon JS, Sedgwick AD, Wadsworth J, Westmacott D, Wilkinson SE: Potent selective inhibitors of protein kinase C. FEBS Lett 1989;259:61-63.

21 Van Hinsbergh VW, Kooistra T, Scheffer MA, Hajo van Bockel J, van Muijen GN: Characterization and fibrinolytic properties of human omental tissue mesothelial cells. Comparison with endothelial cells. Blood 1990;75:14901497.

22 Chomczynski P, Sacchi N: Single-step method of RNA isolation by acid guanidinium thiocyanate-phenol-chloroform extraction. Anal Biochem 1987;162:156-159.

23 Ayo SH, Radnik R, Garoni JA, Troyer DA, Kreisberg JI: High glucose increases diacylglycerol mass and activates protein kinase $\mathrm{C}$ in mesangial cell cultures. Am J Physiol 1991; 261:F571-F577.

24 Ihm CG, Park JK, Hong SP, Lee TW, Cho BS, Kim MJ, Cha DR, Ha H: A high glucose concentration stimulates the expression of monocyte chemotactic peptide 1 in human mesangial cells. Nephron 1998;79:33-37. 